\author{
N.A. Bokayev, A.A. Khairkulova* \\ L.N. Gumilyov Eurasian national university, Nur-Sultan, Kazakhstan \\ (E-mail: bokayev2011@yandex.ru, aitbekovna3@mail.ru)
}

\title{
On the boundedness of the fractional maximal operator on global Orlicz-Morrey spaces
}

\begin{abstract}
The article deals with the global Orlia-Morrey spaces $G M_{\Phi, \varphi, \theta}\left(R^{n}\right)$. We find sufficient conditions on pairs of functions $(\varphi, \eta)$ and $(\Phi, \Psi)$, which ensure the boundedness of the fractional maximal operator $M_{\alpha}$ from $G M_{\Phi, \varphi, \theta}\left(R^{n}\right)$ in $G M_{\Psi, \eta, \theta}\left(R^{n}\right)$. It is proved that under some additional conditions on the function $\varphi$, the conditions obtained are also necessary. In the proof, the boundedness condition is essentially used, the maximal Hardy-Littlewood functions and the estimate of the norm of the characteristic function in global Orlicz-Morrey spaces are used.
\end{abstract}

Keywords: Orlicz space, Morrey type space, the fractional maximal functions, the global Orlicz-Morrey spaces.

\section{Introduction}

The classical Morrey space was introduced in the works of Charles Morrey in 1938 [1] in connection with the study of the solution of quasilinear elliptic differential equations. Inrecent decades, the boundedness of various operators in spaces of Morrey type has been actively studied. This paper, we consider the boundedness of the fractional maximal functions in global Orlicz-Morrey spaces. We note that the issues of the boundedness of the fractional maximal operator and the Riesz potential in various function spaces are well studied. For classical Lebesgue spaces they are detailed in monographs $[2,3]$.

We give definitions of the classical operators of the theory of functions and various Morrey spaces of interest to us and some papers in which the boundedness of these operators in these spaces is considered.

The Hardy-Littlewood maximal operator

$$
M f(x)=\sup _{r>0} \frac{1}{|B(x, r)|} \int_{B(x, r)}|f(y)| d y
$$

is bounded on $L_{p}$ for $1<p<\infty$.

Let $f \in L_{1}^{\text {loc }}\left(R^{n}\right)$. The fractional maximal operator $M_{\alpha}$ are defined by

$$
M_{\alpha} f(x)=\sup _{r>0}|B(x, r)|^{\frac{\alpha}{n}-1} \int_{B(x, r)}|f(y)| d y, 0 \leq \alpha<n,
$$

where $B(x, r)$ is an open ball centered at a point $x \in R^{n}$ of radius $r>0$. If $\alpha=0$, then $M_{0} \equiv M$ is the Hardy-Littlewood maximal operator.

The classical Morrey spaces $M_{p, \lambda}\left(R^{n}\right)$ are defined as the set of all functions $f \in L_{p}^{\text {loc }}\left(R^{n}\right)$ for which

$$
\|f\|_{M_{p, \lambda}\left(R^{n}\right)}=\sup _{x, r>0} r^{-\lambda / p}\|f\|_{L_{p}(B(x, r))}
$$

where $0 \leq \lambda \leq n, 1 \leq p<\infty$. It's clear that $\|f\|_{M_{p, 0}\left(R^{n}\right)} \equiv\|f\|_{L_{p}\left(R^{n}\right)},\|f\|_{M_{p, \frac{n}{p}}\left(R^{n}\right)} \equiv\|f\|_{L_{\infty}\left(R^{n}\right)}$.

Let $1 \leq p \leq \infty, \omega$ be measurable non-negative function on $(0, \infty)$, not equivalent to zero. The generalized Morrey spaces $M_{p, \omega(\cdot)} \equiv M_{p, \omega(\cdot)}\left(R^{n}\right)$ are defined as the set of all functions $f \in L_{p}^{l o c}\left(R^{n}\right)$ with finite norm

$$
\|f\|_{M_{p, \omega(\cdot)}} \equiv \sup _{x \in R^{n}, r>0}\left(\omega(r)\|f\|_{L_{p}(B(x, r))}\right)<\infty .
$$

\footnotetext{
${ }^{*}$ Corresponding author.

E-mail: aitbekovna3@mail.ru
} 
The generalized Morrey space $M_{p, \omega(\cdot)}$ coincides with the classical Morrey spaces for $\omega(r)=r^{-\lambda}$ where $0 \leq \lambda \leq \frac{n}{p}$

The generalized Morrey space $M_{p, \omega(\cdot)} \equiv M_{p, \omega(\cdot)}\left(R^{n}\right)$ introduced by (Mizuhara, Nakai 1990, 1994) $[4,5]$ and they were reviewed in [6], in which various sufficient conditions are given for the boundedness of the maximal Hardy-Littlewood functions, the fractional maximal functions and the Riesz potential in these spaces. Global Morrey-type spaces $G M_{p, \theta, \omega(\cdot)}\left(R^{n}\right)$ and the local Morrey spaces were considered by of Burenkov V.I., Guliev V.S., A.Gogatishvili, R. Mustafaev ([7-9]), in which various sufficient, and for some values of the parameters, necessary conditions for the boundedness of the maximal Hardy-Littlewood functions, the fractional maximal functions in these spaces are obtained.

Let $1 \leq p \leq \infty, 1 \leq \theta \leq \infty, \omega$ be measurable non-negative function on $(0, \infty)$, not equivalent to zero. The global Morrey spaces $G M_{p, \theta, \omega(\cdot)} \equiv G M_{p, \theta, \omega(\cdot)}\left(R^{n}\right)$ are defined as the set of all functions $f \in L_{p}^{\text {loc }}\left(R^{n}\right)$ with finite quasinorm

$$
\|f\|_{G M_{p, \theta, \omega(\cdot)}} \equiv \sup _{x \in R^{n}}\|\omega(r)\| f\left\|_{L_{p}(B(x, r))}\right\|_{L_{\theta}(0, \infty)},
$$

where $B(x, r)$ is an open ball centered at a point $x \in R^{n}$ of radius $r>0$.

The spaces $G M_{p, \theta, \omega(\cdot)}\left(R^{n}\right)$ coincides with the generalized Morrey space $M_{p, \omega(\cdot)}\left(R^{n}\right)$ at $\theta=\infty$.

The results on the boundedness of various classical operators in the theory of functions in global and local Morrey spaces (until 2013) are presented in review articles by V. I. Burenkov [10, 11].

Another well-known space that generalizes Lebesgue space $L_{p}$ is the space introduced by Orlicz ([12]).

We recall the definition of Young functions.

A function $\Phi:[0,+\infty] \rightarrow[0, \infty]$ is called Young's function if $\Phi$ is a convex function, left continuous, and such that

$$
\lim _{r \rightarrow+0} \Phi(r)=\Phi(0)=0, \lim _{r \rightarrow+\infty} \Phi(r)=\infty .
$$

From the convexity of the function and $\Phi(0)=0$ it follows that any Young function is increasing.

If there is $s \in(0, \infty)$ such that $\Phi(s)=\infty$, then $\Phi(r)=\infty$ for $r \geq s$.

Let $E$ be the set of all Young functions $\Phi$ such that

$$
0<\Phi(r)<+\infty
$$

for

$$
0<r<+\infty
$$

If $\Phi \in E$, then $\Phi$ is absolutely continuous on every closed interval in $[0, \infty)$ and bijective from $[0, \infty)$ to itself.

For a Young function $\Phi$, the set

$$
L_{\Phi}\left(R^{n}\right)=\left\{f \in L_{1}^{\text {loc }}\left(R^{n}\right): \int_{R^{n}} \Phi(k|f(x)|) d x<+\infty, \text { for some } k>0\right\}
$$

is called Orlicz space. In the works $[13,14]$ the questions of the boundedness of classical operators of the theory of functions in Orlicz spaces were studied.

If $\Phi(r)=r^{p}, 1 \leq p<\infty$, then $L_{\Phi}\left(R^{n}\right)=L_{p}\left(R^{n}\right)$. If $\Phi(r)=0(0 \leq r \leq 1)$ and $\Phi(r)=\infty(r>1)$, then $L_{\Phi}\left(R^{n}\right)=L_{\infty}\left(R^{n}\right)$.

$L_{\Phi}\left(R^{n}\right)$ is a Banach space with respect to the norm

$$
\|f\|_{L_{\Phi}\left(R^{n}\right)}=\inf \left\{\lambda>0: \int_{R^{n}} \Phi\left(\frac{|f(x)|}{\lambda}\right) d x \leq 1\right\} .
$$

We note that

$$
\int_{R^{n}} \Phi\left(\frac{|f(x)|}{\|f\|_{L_{\Phi}}}\right) d x \leq 1 .
$$

For Young's function $\Phi$ and $0 \leq s \leq+\infty$ let

$$
\Phi^{-1}(s)=\inf \{r \geq 0: \Phi(r)>s\} .
$$

If $\Phi \in E$, then $\Phi^{-1}$ this is the usual inverse function for $\Phi$. We note that

$$
\Phi\left(\Phi^{-1}(r)\right) \leq r \leq \Phi^{-1}(r), \text { for } 0 \leq r<\infty .
$$


A Young function $\Phi$ is said to satisfy the $\triangle_{2}$-condition, denoted by $\Phi \in \triangle_{2}$, if

$$
\Phi(2 r) \leq k \Phi(r), \text { for } r>0
$$

for some $k>1$.

A Young function $\Phi$ is said to satisfy the $\nabla_{2}$-condition, denoted also by $\Phi \in \nabla_{2}$, if

$$
\Phi(r) \leq \frac{1}{2 k} \Phi(k r), r \geq 0
$$

for some $k>1$. The function $\Phi(r)=r$ satisfies the $\triangle_{2}$-condition but does not satisfy the $\nabla_{2}$-condition. If $1<p<\infty$, then $\Phi(r)=r^{p}$ satisfies the $\nabla_{2}$-condition but does not satisfy the $\triangle_{2}$-condition.

A Young function $\Phi$ is said to satisfy the $\triangle^{\prime}$ - condition, denoted also as $\Phi \in \triangle^{\prime}$, if

$$
\Phi(t r) \leq k \Phi(t) \Phi(r), t, r \geq 0
$$

for some $k>1$. If $\Phi \in \nabla_{2}$, then $\Phi \in E$.

The boundedness conditions for classical operators of the theory of functions in generalized Orlicz-Morrey spaces $M_{\Phi, \varphi}$ were considered by V.S.Guliyev, F.Deringoz, S.Samko and others [15-18].

The purpose of this paper is to consider global Orlicz-Morrey spaces $G M_{\Phi, \varphi, \theta}\left(R^{n}\right)$ (the corresponding definition is given in the next section) and find conditions for the boundedness the fractional maximal functions in these spaces.

\section{Definitions, notation, and auxiliary statements}

We give the definition of global Orlicz-Morrey spaces in the following way:

Definition 1. Let $\varphi(x, r)$ be a positive, measurable function on $R^{n} \times(0, \infty)$ and $\Phi$ be a Young function, $1 \leq \theta \leq \infty$. We defined the global Orlicz-Morrey spaces $G M_{\Phi, \varphi, \theta}=G M_{\Phi, \varphi, \theta}\left(R^{n}\right)$ as the set of all functions $f \in L_{\Phi}^{\text {loc }}\left(R^{n}\right)$ with finite quasinorm

$$
\|f\|_{G M_{\Phi, \varphi, \theta}}=\sup _{x \in R^{n}}\left\|\varphi(x, r)^{-1} \Phi^{-1}\left(|B(x, r)|^{-1}\right)\right\| f\left\|_{L_{\Phi}(B(x, r))}\right\|_{L_{\theta}(0, \infty)} .
$$

At $\theta=\infty$ the corresponding space is called the generalized Orlicz-Morrey space $M_{\Phi, \varphi}$.

Let $\varphi(x, r)$ be a positive, measurable function on $R^{n} \times(0, \infty)$ and $\Phi$ be a Young function. We denote by $M_{\Phi, \varphi}$ the generalized Orlicz-Morrey spaces, the space of all functions $f \in L_{\Phi}^{\text {loc }}\left(R^{n}\right)$ with finite quasinorm

$$
\|f\|_{M_{\Phi, \varphi}}=\sup _{x \in R^{n}, r>0} \varphi(x, r)^{-1} \Phi^{-1}\left(|B(x, r)|^{-1}\right)\|f\|_{L_{\Phi}(B(x, r))} .
$$

At $\Phi(r)=r^{p}, 1 \leq p<\infty$ the corresponding global Orlicz-Morrey space is denoted by $G M_{p, \varphi, \theta}\left(R^{n}\right)$ :

$$
G M_{p, \varphi, \theta}\left(R^{n}\right)=\left.G M_{\Phi, \varphi, \theta}\left(R^{n}\right)\right|_{\Phi(r)=r^{p}} .
$$

At

$$
\varphi(x, r)=\left(\Phi^{-1}\left(r^{-n}\right) / \Phi^{-1}\left(r^{-\lambda}\right)\right)
$$

the corresponding global Orlicz-Morrey space is denoted by $G M_{\Phi, \lambda, \theta}\left(R^{n}\right)$ :

$$
G M_{\Phi, \lambda, \theta}\left(R^{n}\right)=\left.G M_{\Phi, \varphi}\right|_{\varphi(x, r)=\Phi^{-1}\left(r^{-n}\right) / \Phi^{-1}\left(r^{-\lambda}\right)}
$$

At $\Phi(r)=r^{p}, 1 \leq p<\infty$ and $\varphi(x, r)=\left(\Phi^{-1}\left(r^{-n}\right) / \Phi^{-1}\left(r^{-\lambda}\right)\right)$ the global Orlicz-Morrey space coincides with the Morrey space, i.e. $G M_{p, \lambda, \infty}\left(R^{n}\right)=M_{p, \lambda}\left(R^{n}\right)$.

Let $\Phi$ be a Young function. We denote by $\Omega_{\Phi}$ the sets of all positive measurable functions $\varphi$ on $R^{n} \times(0, \infty)$ such that for all $t>0$,

$$
\sup _{x \in R^{n}}\left\|\frac{\Phi^{-1}\left(|B(x, r)|^{-1}\right)}{\varphi(x, r)}\right\|_{L_{\infty}(t, \infty)}<\infty
$$

and

$$
\sup _{x \in R^{n}}\left\|\varphi(x, r)^{-1}\right\|_{L_{\infty}(0, t)}<\infty
$$

respectively. 
We give auxiliary statements that we will need in the proof of the main statement.

By $\chi_{B}$ we denote the characteristic function of the set $B$.

Lemma 1. [16] Let $\Phi$ be a Young's function and $B$ a set in $R^{n}$ finite Lebesgue measure. Then

$$
\left\|\chi_{B}\right\|_{L_{\Phi}}=\frac{1}{\Phi^{-1}\left(|B|^{-1}\right)} .
$$

Lemma 2. [16] Let $0<\alpha<n, 1<\theta<\infty$ and function $\varphi(x, t)$ satisfies condition

$$
t^{\alpha} \varphi(x, t)+\left\|r^{\alpha-1}\right\|_{L_{\theta}(t, \infty)} \leq C \varphi(x, t)^{\beta}
$$

for some $\beta \in(0,1)$ and for each $x \in R^{n}$ and $t>0$. Then there is pointwise inequality

$$
M_{\alpha} f(x) \leq C(M f(x))^{\beta} \cdot\|f\|_{G M_{\Phi, \varphi, \theta}} .
$$

Lemma 3. [16] If $B_{0}=B\left(x_{0}, r_{0}\right)$, then $r_{0}^{\alpha} \leq C M_{\alpha} \chi_{B_{0}}(x)$ for every $x \in B_{0}$.

A function $\varphi:(0, \infty) \rightarrow(0, \infty)$ is said to be almost increasing (respectively, almost decreasing) if there exists a constant $c>0$ such that

$$
\varphi(r) \leq C \varphi(s)(\text { respectively } \varphi(r) \geq C \varphi(s), \text { for } r \leq s) .
$$

For Young's function $\Phi$ we denote by $£_{\Phi}$ the set of all almost decreasing functions $\varphi:(0, \infty) \rightarrow(0, \infty)$ such that $t \in(0, \infty) \mapsto \frac{\varphi(t)}{\Phi^{-1}\left(t^{-n}\right)}$ is almost increasing.

Lemma 4. Let $B_{0}:=B\left(x_{0}, r_{0}\right)$. If $\varphi \in £_{\Phi}$ then there exist $c>0$ such that

$$
\frac{1}{\varphi\left(r_{0}\right)} \leq\left\|\chi_{B_{0}}\right\|_{G M_{\Phi, \varphi, \theta}} \leq \frac{C}{\varphi\left(r_{0}\right)} .
$$
have:

Proof. Let $B_{s}=B(x, s)$ arbitrary ball from $R^{n}$. If $s \leq r$, then $\varphi(r) \leq C \varphi(s)$ and according to Lemma 1 we

$$
\varphi(s)^{-1} \Phi^{-1}\left(|B|^{-1}\right)\left\|\chi_{B}\right\|_{L_{\Phi}(B)} \leq \frac{1}{\varphi(s)} \leq \frac{C}{\varphi(r)} .
$$

Hence

$$
\left\|\varphi(s)^{-1} \Phi^{-1}\left(|B|^{-1}\right)\right\| \chi_{B}\left\|_{L_{\Phi}(B)}\right\|_{L_{\theta}(0, \infty)} \leq \frac{C}{\|\varphi(r)\|_{L_{\theta}(0, \infty)}} .
$$

Means

$$
\left\|\chi_{\Phi}\right\|_{G M_{\Phi, \varphi, \theta}} \leq \frac{C}{\|\varphi(r)\|_{L_{\theta}(0, \infty)}} .
$$

If $s \geq r$ then by $\varphi \in £_{\Phi}$ we have:

$$
\frac{\varphi(r)}{\Phi^{-1}\left(\left|B_{0}\right|^{-1}\right)} \leq C \frac{\varphi(s)}{\Phi^{-1}\left(|B|^{-1}\right)}
$$

therefore

it follows that

$$
\varphi(r)^{-1} \Phi^{-1}\left(|B|^{-1}\right)\left\|\chi_{B_{0}}\right\|_{L_{\Phi}(B)} \leq \frac{C}{\varphi(r)},
$$

$$
\left\|\chi_{B}\right\|_{G M_{\Phi, \varphi, \theta}} \leq \frac{C}{\|\varphi(r)\|_{L_{\theta}(0, \infty)}} .
$$

Lemma 4 is proved.

\section{Results for fractional maximal operator in global spaces of Orlicz-Morrey type}

Theorem 1. Let $\Phi \in \triangle^{\prime} \cap \nabla_{2}$, and $0<\alpha<n, 1<\theta<\infty$. Let $\varphi \in \Omega_{\Phi}$ satisfies condition

$$
r^{\alpha} \varphi(x, r)+\sup _{r<t<\infty} t^{\alpha} \varphi(x, t) \leq C \varphi(x, r)^{\beta}
$$


for some $\beta \in(0,1)$ and for every $x \in R^{n}$ and $r>0$. Define $\eta(x, r)=\varphi(x, r)^{\beta}$, and $\Psi(r)=\Phi\left(r^{1 / \beta}\right)$. The maximal operator $M$ the bounded in $G M_{\Phi, \varphi, \theta}\left(R^{n}\right)$, then the operator $M_{\alpha}$ is bounded from $G M_{\Phi, \varphi, \theta}\left(R^{n}\right)$ to $G M_{\Psi, \eta, \theta}\left(R^{n}\right)$.

Proof. By Lemma 2, we have

$$
M_{\alpha} f(x) \leq C\left(M_{\alpha} f(x)\right)^{\beta} \cdot\|f\|_{G M_{\Phi, \varphi, \theta}}^{1-\beta}, x \in R^{n},
$$

therefore

$$
\left\|M_{\alpha} f(x)\right\|_{L_{\Psi(B)}} \leq C\left\|\left(M_{\alpha} f\right)^{\beta}\right\|_{L_{\Psi}(B)} \cdot\|f\|_{G M_{\Phi, \varphi, \theta}}^{1-\beta}, x \in R^{n}
$$

where $B=B(x, t)$.

It follows from the definition of Orlicz space that

$$
\int_{B} \Psi\left(\frac{(M f(x))^{\beta}}{\|M f\|_{L_{\Phi}(B)}}\right) d x=\int_{B}\left(\Phi \frac{M f(x))}{\|M f\|_{L_{\Phi}(B)}}\right) d x \leq 1 .
$$

Hence

SO

$$
\left\|(M f)^{\beta}\right\|_{L_{\Psi}(B)} \leq\|M f\|_{L_{\Phi}(B)}^{\beta}
$$

$$
\left\|M_{\alpha} f\right\|_{L_{\Psi(B)}} \leq C\|M f\|_{L_{\Psi}(B)}^{\beta} \cdot\|f\|_{G M_{\Phi, \varphi, \theta}}^{1-\beta} .
$$

Based on this inequality, given the boundedness of the maximal operator in $G M_{\Phi, \varphi, \theta}$, we obtain

$$
\begin{gathered}
\left\|M_{\alpha} f\right\|_{G M_{\Psi, \eta, \theta}}=\sup _{x \in R^{n}}\left\|\eta(x, t)^{-1} \Psi^{-1}\left(|B|^{-1}\right)\right\| M_{\alpha} f\left\|_{L_{\Psi}(B)}\right\|_{L_{\theta}(0, \infty)} \leq \\
\leq C\|f\|_{G M_{\Phi, \varphi, \theta}}^{1-\beta} \cdot \sup _{x \in R^{n}}\left\|\varphi(x, t)^{-1} \Phi^{-1}\left(|B|^{-1}\right)\right\| M f\left\|_{L_{\Phi}(B)}^{\beta}\right\|_{L_{\theta}(0, \infty)}= \\
=C\|f\|_{G M_{\Phi, \varphi, \theta}}^{1-\beta}\|M f\|_{G M_{\Phi, \varphi, \theta}}^{\beta} \leq C \cdot\|f\|_{G M_{\Phi, \varphi, \theta}} .
\end{gathered}
$$

Theorem 1 is proved.

Theorem 2. Let $\Phi \in \triangle^{\prime}, 0<\alpha<n, 1<\theta<\infty, \varphi \in \Omega_{\Phi}, \beta \in(0,1), \eta(t) \equiv \varphi(t)^{\beta}$, and $\Psi(t) \equiv \Phi\left(t^{1 / \beta}\right)$.

1. Let $\Phi \in \nabla_{2}$ and the maximal operator $M$ the bounded in $G M_{\Phi, \varphi, \theta}\left(R^{n}\right)$, then the condition

$$
t^{\alpha} \varphi(t)+\left\|r^{\alpha-1} \varphi(r)\right\|_{L_{\theta^{\prime}}(t, \infty)} \leq C \varphi(t)^{\beta}
$$

for all $t>0$, where $C>0$ does not depend on $\mathrm{t}$, is sufficient for the boundedness of $M_{\alpha}$ from $G M_{\Phi, \varphi, \theta}\left(R^{n}\right)$ to $G M_{\Psi, \eta, \theta}\left(R^{n}\right)$.

2. If $\varphi \in £_{\Phi}$, then the condition

$$
\left\|\frac{t^{\alpha}}{\varphi(t)^{\beta}}\right\|_{L_{\theta}(0, \infty)} \leq \frac{C}{\|\varphi(t)\|_{L_{\theta}(0, \infty)}}
$$

is necessary for boundedness of the operator $M_{\alpha}$ from $G M_{\Phi, \varphi, \theta}\left(R^{n}\right)$ to $G M_{\Psi, \eta, \theta}\left(R^{n}\right)$.

3. Let $\Phi \in \nabla_{2}$. If $\varphi \in £_{\Phi}$ satisfies the regularity condition

$$
\left\|r^{\alpha-1} \varphi(r)\right\|_{L_{\theta^{\prime}}(t, \infty)} \leq C t^{\alpha} \varphi(t)
$$

for all $t>0$, where $C>0$ independent of $t$, then the condition (1) is necessary and sufficient for the boundedness $M_{\alpha}$ from $G M_{\Phi, \varphi, \theta}\left(R^{n}\right)$ to $G M_{\Psi, \eta, \theta}\left(R^{n}\right)$.

Proof. The first part follows from Theorem 1 . To prove the second part, we put $B_{0}=B\left(x_{0}, t\right)$, by Lemma 3 , we have

$$
t^{\alpha} \leq C M_{\alpha} \chi_{B_{0}}(x), x \in B_{0} .
$$

We estimate by Lemma 1 ana Lemma 3

$$
t^{\alpha} \leq C \Psi^{-1}\left(\left|B_{0}\right|^{-1}\right)\left\|M_{\alpha} \chi_{B_{0}}\right\|_{L_{\Psi}\left(B_{0}\right)} .
$$

Hence

$$
\frac{t^{\alpha}}{\eta(t)} \leq C \eta^{-1}(t) \Psi^{-1}\left(\left|B_{0}\right|^{-1}\right)\left\|M_{\alpha} \chi_{B_{0}}\right\|_{L_{\Psi}\left(B_{0}\right)}
$$

Mathematics series. № 1(101)/2021 
Therefore

$$
\left\|\frac{t^{\alpha}}{\eta(t)}\right\|_{L_{\theta}(0, \infty)} \leq C\left\|M_{\alpha} \chi_{B_{0}}\right\|_{G M_{\Psi, \eta, \theta}} \leq C\left\|\chi_{B_{0}}\right\|_{G M_{\Phi, \varphi, \theta}} \leq C \frac{1}{\|\varphi(r)\|_{L_{\theta}(r, \infty)}} .
$$

The third part follows from parts 1 and 2. Theorem 2 is proved.

Corollary 1. Let $0<\alpha<n, 1<\theta<\infty, 1<p<q<\infty$ and $\varphi \in \Omega_{p} \equiv \Omega_{t^{p}}$.

1. If $\varphi(t)$ satisfics

$$
\sup _{r<t<\infty} \frac{e s s \inf _{t<s<\infty} \varphi(s) s^{\frac{n}{p}}}{t^{\frac{n}{p}}} \leq C \varphi(r)
$$

then the condition

$$
t^{\alpha} \varphi(t)+\sup _{t<r<\infty} r^{\alpha} \varphi(r) \leq C \varphi(t)^{\frac{p}{q}}
$$

for all $t>0$, where $C>0$ independent of $t$, is sufficient for the boundedness of $M_{\alpha}$ from $G M_{p, \varphi, \theta}\left(R^{n}\right)$ to $G M_{q, \varphi^{\frac{p}{q}}, \theta}\left(R^{n}\right)$.

2. If $\varphi \in £_{p} \equiv £_{t^{p}}$, then the condition

$$
t^{\alpha} \varphi(t) \leq C \varphi(t)^{\frac{p}{q}}
$$

for all $t>0$, where $C>0$ independent of $t$, is necessary for the boundedness of $M_{\alpha}$ from $G M_{p, \varphi, \theta}\left(R^{n}\right)$ to $G M_{q, \varphi^{\frac{p}{q}, \theta}}\left(R^{n}\right)$.

3. If $\varphi \in £_{p}$ then the condition (2) is necessary and sufficient for the boundedness of $M_{\alpha}$ from $G M_{p, \varphi, \theta}\left(R^{n}\right)$ to $G M_{q, \varphi^{\frac{p}{q}, \theta}}\left(R^{n}\right)$.

If we take $\varphi(t)=\frac{\Phi^{-1}\left(t^{-n}\right)}{\Phi^{-1}\left(t^{-\lambda}\right)}, 0 \leq \lambda \leq n, \Psi(t) \equiv \Phi\left(t^{\frac{1}{\beta}}\right), \beta \in(0,1)$,

$$
\eta(t) \equiv \varphi(t)^{\beta}=\left(\frac{\Phi^{-1}\left(t^{-n}\right)}{\Phi^{-1}\left(t^{-\lambda}\right)}\right)^{\beta}=\frac{\Psi^{-1}\left(t^{-n}\right)}{\Psi^{-1}\left(t^{-\lambda}\right)}
$$

at Theorem 2 we get the following result.

Corollary 2. Let $\Phi \in \triangle^{\prime} \cap \nabla_{2}, \Psi(t) \equiv \Phi\left(t^{1 / \beta}\right)$ and $\beta \in(0,1)$. If

$$
\sup _{t<r<\infty} r^{\alpha} \frac{\Phi^{-1}\left(r^{-n}\right)}{\Phi^{-1}\left(r^{-\lambda}\right)} \leq C t^{\alpha} \frac{\Phi^{-1}\left(t^{-n}\right)}{\Phi^{-1}\left(t^{-\lambda}\right)}
$$

for all $t>0$, where $C>0$ independent of $t$, then the condition

$$
t^{\alpha} \leq C\left[\frac{\Phi^{-1}\left(t^{-n}\right)}{\Phi^{-1}\left(t^{-\lambda}\right)}\right]^{\beta-1}
$$

for all $t>0$, where $C>0$ independent of $t$, is necessary and sufficient for the boundedness of $M_{\alpha}$ from $G M_{\Phi, \lambda}\left(R^{n}\right)$ to $G M_{\Psi, \lambda}\left(R^{n}\right)$.

Remark. The Theorem 1 and 2 are an Adams type result. The similar theorem for the generalized OrliczMorrey spaces $M_{\Phi, \varphi}$ was proved in [16-18].

\section{References}

1 Morrey, Ch. (1938). On the solutions of quasi-linear elliptic partial differential equations. Trans. Amer. Math. Soc., 126-166.

2 Stein, E.M. (1970) Singular Integrals and Differentiability Properties of Functions. Princeton, New Jersey: Princetion University Press.

3 Torchinsky, A. (1986) Real-Variable Methods in Harmonic Analysis. Academic Press INC.

4 Mizuhara, T. (1991). Boundedness of some classical operators on generalized Morrey spaces Harmonic Analisis (S.Igari, Editor) ICM 90 Satellite Proceedings, Springer-Verlag, Tokyo, 183-189.

5 Nakai, E. (1994). Hardy-Littlewood maximal operator, singular integral operators and the Riesz potential on generalized Morrey spaces. Math. Nachr., 166(1), 95-103. 
6 Guliyev, V.S. (2009). Boundedness of the maximal, potential and singular operators in the generalized Morrey spaces. J.Inequal. Appl., 503948.

7 Burenkov, V.I., \& Guliyev, H.V. (2004). Necessary and sufficient conditions for boundedness of the maximal operator in the local Morrey-type spaces. Studia Mathematica., 163(2), 157-176.

8 Burenkov, V.I., Gogatishvili, A., Guliyev, V.S., \& Mustafaev, R. (2010). Boundedness of the maximal operator in the local Morrey-type spaces. Complex Analysis and Elliptic Equations 55(8-10), 739-758.

9 Burenkov V.I., \& Goldman, M.L. (2014). Necessary and sufficient conditions for boundedness of the maximal operator from Lebesgue spaces to Morrey-type spaces. Mathematical Inequalities and Applications. Accepted for publication. Math.Inequal.Appl. 17(2), 401-418.

10 Burenkov, V.I. (2012). Recent progress in studying the boundedness of classical operators of real analysis in general Morrey-type spaces I. Eurasian Math. J. 3(3), 11-32.

11 Burenkov, V.I. (2013). Recent progress in studying the boundedness of classical operators of real analysis in general Morrey-type spaces II. Eurasian Math. J. 4(1), 21-45.

12 Krasnoselskii, M.A., \& Rutickii, Ja.B. (1961). Convex Functions and Orlicz Spaces. P.Noordhoff, Groningen, The Netherlands.

13 Kita, H. (1997). On Hardy-Littlewood maximal functions in Orlicz spaces. Math. Nachr., 183, $135-155$.

14 Cianchi, A. (1999). Strong and weak type inequalities for some classical operators in Orlicz spaces. J. London Math. Soc. 60(2), 187-202.

15 Deringoz, F., Guliyev, V.S., \& Samko, S. (2014). Boundedness of the maximal operator and singular operators on generalized Orlicz-Morrey spaces. Operator Theory, Operator Algebras and Applications, Series: Operator Theory: Advances and Applications, 242, 139-158.

16 Deringoz, F., Guliyev, V.S., \& Hasanov, S.G. (2017). A characterizations for Adams-type boundedness of the fractional maximal operator on generalized Orlicz-Morrey spaces. arXiv: 1610.09823v2 [math.FA], $1-20$.

17 Deringoz, F., \& Guliyev, V.S. (2014). On the Riesz potential and its commutators on generalized OrliczMorrey spaces. Hindawi Publishing Corporation Journal of Function Spaces Volume, 1-11.

18 Sawano, Y., Sugano, S., \& Tanaka, H. (2012). Orlicz-Morrey spaces and fractional operators. Potential Analysis, 3(4), 517-556.

\author{
Н.А. Бокаев, А.А. Хайркулова
}

\title{
Бөлшек максималды оператордың Орлич-Морри кеңістігіндегі шекарасы
}

\begin{abstract}
Мақалада $G M_{\Phi, \varphi, \theta}\left(R^{n}\right)$ ғаламдық Орлич-Морри кеңістігі қарастырылған. Авторлар $(\varphi, \eta)$ және $(\Phi, \Psi)$ функцияларының жұптары үшін $M_{\alpha}$ бөлшек максималды операторының шекарасын қамтамасыз ететін жеткілікті шарттарды тапқан. $G M_{\Phi, \varphi, \theta}\left(R^{n}\right)$ кеңістігінен $G M_{\Psi, \eta, \theta}\left(R^{n}\right)$ кеңістігіне $\varphi$ функциясы бойынша кейбір қосымша заңдылық шарттарында алынған шарттар да қажет екендігі дәлелденді. Дәлелдеуде негізінен шектілік шарты максималды Харди-Литтвуд функциялары және ғаламдық Орлич-Морри кеңістігіндегі сипаттамалық функция нормасы қолданылған.
\end{abstract}

Kiлm сөздер: Орлич кеңістігі, Морри типті кеңістік, бөлшек максималды функциялар, жалпыланған Орлич-Морри кеңістіктері. 
Н.А. Бокаев, А.А. Хайркулова

\section{Об ограниченности дробного максимального оператора в глобальных пространствах Орлича-Морри}

В статье рассмотрены глобальные пространства Орлича-Морри $G M_{\Phi, \varphi, \theta}\left(R^{n}\right)$. Авторы находят достаточные условия на пары функций $(\varphi, \eta)$ и $(\Phi, \Psi)$, которые обеспечивают ограниченность дробномаксимального оператора $M_{\alpha}$ из $G M_{\Phi, \varphi, \theta}\left(R^{n}\right)$ в пространство $G M_{\Psi, \eta, \theta}\left(R^{n}\right)$. Доказано, что при некоторых дополнительных условиях регулярность на функцию $\varphi$, полученные условия являются необходимыми. При доказательстве существенно использованы условие ограниченности, максимальные функции Харди-Литлвуда и оценка нормы характеристической функции в глобальных пространствах Орлича-Морри.

Ключевые слова: пространство Орлича, пространство типа Морри, дробные максимальные функции, глобальные пространства Орлича-Морри. 